\title{
Oligarkiaa ja harvainvaltaa
}

\author{
Matti Parjanen
}

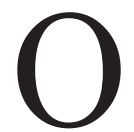

lemme nyt yliopiston päärakennuksen luentosalissa A1 ${ }^{1 .}$ Tässä salissa on ehtinyt väitellä jopa satoja yliopistomme tohtoreita. Väitöstilaisuus on useimmiten kuiva akateeminen näytelmä, jonka loppukohtauksen kaikki katsojat tietävät jo etukäteen. Kuivattaminen alkaa jo vastaväittäjän ensimmäisestä puheenvuorosta. Traditionaalisesti hän nimittäin alkaa saivarrella väitöskirjan otsikosta, erityisesti siitä, vastaako kirjan otsikko sisältöä. Tähän väittelyyn voi joskus huveta kymmeniä minuutteja.

Otsikkoni on "Oligarkiaa ja harvainvaltaa Tampereen yliopistossa". Tiedän, että monet nuoremmat yliopistolaiset ovat ihmetelleet, miksei 40 vuotta yliopistossa töitä tehnyt puhuja tiedä, että kreikkalaisperäinen sivistyssana "oligarkia" on suomeksi käännettynä nimenomaan "harvainvalta”. Tätä mielipidettä olenkin odottanut, sillä juuri Tampereen yliopiston historiaa vähän tuntevien hämääminen olikin tarkoitukseni. Toisaalta katson, että kaikissa väitöskirjoissakin pitäisi olla mukana tieteellistä mielikuvitusta, imaginaatiota. Mielikuvitus saa usein ilmenemismuotonsa siinä, että tutkija, kirjoittaja tai puhuja ymmärtää kielen ja sen yksittäisten sanojenkin symboleja, metaforia, lisä- ja piilomerkityksiä.

Tässä tapauksessa oligarkia liittyy Tampereen yliopiston 77-vuotisen historian tunnetuimman rehtorin Paavo Olavi Kolin toistaiseksi eniten julkisuutta herättäneeseen lukuvuoden avajaispuheeseen vuonna 1966. Sitä media kutsui nimellä "Oligarkiapuhe". "Harvainvallalla" puolestaan viittaan yliopistomme toiseen rehtoriin, Urpo Hemminki Harvaan, joka mielellään käytti nimeensä liittyviä konnotaatioita, kuten juuri harva(i)nvaltaa iillä tai ilman iitä.

Nämä monimerkityksellisyydet kuultuaan moni teistä haluaisikin heti poistua salista, sillä tahallinen sanoilla leikkimiseni on ilmeisesti tuonut tänne ihmisiä kuulemaan suurella kiinnostuksella eläkkeelle siirtyvän henkilön (jolla siis ei ole enää mitään hävittävää) paljastuksia Tampereen yliopiston nykyisen johdon vallanhimosta ja hallinnon mädännäisyydestä. Tähän totean vain, että osaavat sitä muutkin sanojen järjestyksillä leikkiä. Kolin ja Harvan aikaan Tampereen yliopistossa oli selkeästi keskushallinto, nyt se on nimeltään hallintokeskus. Enpä usko, että "keskus"-sanan heittäminen alusta loppuun vielä tekee siitä edeltäjäänsä demokraattisemman.

\section{Kahden rehtorin taustoista}

Sen verran olen antanut tartuttaa itseeni nykyistä yliopistopolitiikan markkinahinkuista yskää, että tällä kertaa en halua kertoakaan kaikkea sitä, mitä tiedän. Olen nimittäin ryhtynyt kirjoittamaan Paavo Kolin elämäkertaa, jota varten olen ehtinyt tähän mennessä haastatella noin 60 hänen aikalaistaan. En saa kuulemma kirjaani kaupaksi, jos lavertelen sisällöt jo etukäteen!

Muutama sana "Oligarkia-Kolin" ja "Harvainvalta-Harvan" elämästä. Urpo Harva syntyi Vampulassa vuonna 1910 ja kuoli 84-vuotiaana seitsemän vuotta sitten. Hänen nimensä oli alunperin Heerman. Hänen opiskelunsa Turun yliopistossa oli varsin ripeää. Ensin 2.5 vuodessa filosofian kandidaatiksi. Aineyhdistelmään kuului kolme laudatur-arvosanaa: filosofiassa, pedagogiikassa ja sosiologiassa. Sitten taas pari vuotta lisää, ja hän väitteli tohtoriksi, vain 24-vuotiaana. Säännöllisin väliajoin tiedotusvälineet listaavat Suomen nuorimmat väittelijät. Näistä akateemisista pikaluvun tuloslistoista aina puuttuu Urpo Harvan nimi, vaikka hän todellisuudessa oli mitaleilla. Hänen saksankielinen väitöskirjansa käsitteli G.I. Hartmanin filosofiaa. Harva toimi vuodesta 1940 kansansivistysopin opettajana Yhteiskunnallisessa Korkeakoulussa, ja hänet nimitettiin vuonna 1946 kansansivistysopin professoriksi. Myöhem- 
min viran ala ja oppiaineen nimi muutettiin aikuiskasvatukseksi. Tämä virka on ensimmäinen yliopistomme professuuri. Tätä ennen oli alan professorin virka maailmassa vain USA:ssa ja Englannissa. Ei ollut ihme, että yliopistollamme katsottiin olleen pitkään monopoli Suomessa tieteenalan tutkijoiden ja käytännön aikuiskasvattajien kouluttajana. Urpo Harva oli Yhteiskunnallisen Korkeakoulun rehtorina kolme vuotta heti sodan jälkeen, ja hän jäi eläkkeelle yli 30 vuotta kestäneen virkauransa jälkeen vuonna 1973.

Paavo Koli syntyi Oulussa 1921, joten hän oli Harvaa 11 vuotta nuorempi. Jos Harva oli aikaisemmalta nimeltää Heerman, niin Kolin varusmiesaikainen kämppäkaveri Kalle Päätalo on suomentanut Paavo Kolin nimen kirjassaan "Liekkejä laulumailla" miehistön kanssa hyvin toimeentulevaksi vänrikki Hiileksi. Koli kävi Kadettikoulun jatkosodan aikana, mutta luopui sotilaan urasta heti sodan jälkeen, jolloin aloitti opintonsa sekä valtiotieteellisessä tiedekunnassa että voimistelulaitoksella Helsingin yliopistossa. Kolin luonnetta ja tulevaa elänkaarta kuvaa hyvin hänen motivaationsa lähteä opiskelemaan Kadettikouluun. Syitä oli kaksi. 1) Tällä tavoin pääsi paikolleen juuttuneen asemasodan tylsältä rintamalta vilkkaammille rintamaille, pääkaupunkiin; 2) Hän on itse ilmaissut motivaationsa seuraavasti: "Halusin tutustua sotakoulujen määrätietoisiin koulutusperiaatteisiin oppiakseni, en tullakseni tai jäädäkseni upseeriksi, vaan kehittääkseni itseäni tulevaisuutta varten... Mikäli nyt sodassa jään henkiin.”

Ei Kolikaan paljoa viivytellyt opinnoissaan, sillä jo kolmen vuoden kuluttua hänellä oli tutkinnot suoritettuina molemmilla koulutusaloilla. Koli vietti vuoden Asla-stipendiaattina Yhdysvalloissa tasan 50 vuotta sitten. Hän ei koskaan itse ehtinyt kuulla, että hänet on nyttemmin nimitetty Asla-stipendiaatti Numero 1:ksi, koska hän ehti ensimmäisenä perille valtameren yli. Sodan raiskaaman Euroopan jälkeen potentiaaleja etsivä Amerikka teki Koliin niin suuren vaikutuksen, ettei hän koko elämänsä aikana päässyt siitä täysin irti. Stipendimatkalla hän sai myös kipinän ryhtyä kirjoittamaan sosiologian väitöskirjaansa, joka valmistui 1955 nimeltään "Ennakkoluuloista teollisessa organisaatiossa".

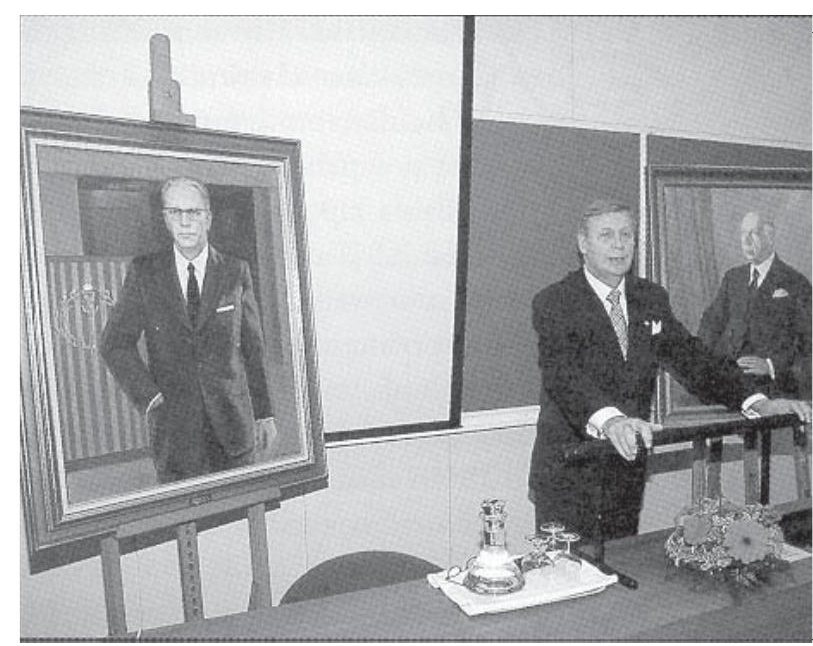

Matti Parjanen herrojen Paavo Koli ja Urpo Harva seurassa. Kuva: Erkki Karén

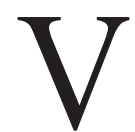

uosi 1959 oli tärkeä sekä Kolille että myös minulle. Tulimme silloin yhtä aikaa Yhteiskunnalliseen Korkeakouluun, hän sosiologian vt. professoriksi ja minä kansansivistysopin, myöhemmältä nimeltään aikuiskasvatuksen, opiskelijaksi. Tämän jäähyväisluennon aihepiiriin sopii luontevasti mainita, että kyllästyin jo ensimmäisenä vuotena kuuntelemaan pääaineeni professorin Urpo Harvan omasta mielestäni liiaksi filosofialla raskautettuja kansansivistysopin luentoja. Kuunneltuani muutaman tunnin Paavo Kolin peruskurssin luentoja ei minulla ollut minkäänlaista epäröintiä vaihtaa pääaineeni sosiologiaan. Oltuani toistakymmentä vuotta yliopistomme täydennyskoulutuskeskuksen johtajana palautuivat mieleeni perustelut pääaineen vaihtamiselleni fuksivuotena: totesin silloin usein ääneen, etten kuitenkaan tulisi koskaan elämässäni tarvitsemaan aikuiskasvatusta. Nyt voin vain huomata, että suurin osa tieteellisestä tuotannostani asettuu nimenomaan aikuiskasvatuksen ja sosiologian tangeerauskohtiin.

Paavo Koli nimitettiin sosiologian professorin virkaan vuonna 1961, mutta hän ei saanut kauan nauttia tavallisen kenttäprofessorin enemmän tai vähemmän tasaisesta elämästä. Hänet nimittäin valittiin jo viikon kuluttua korkeakoulun vararehtoriksi ja muutaman kuukauden kuluttua korkeakoulun rehtoriksi kesällä 1962. Siitä tehtävästä hän luopui vuoden 1969 alussa, kolme ja puoli kuukautta ennen kuolemaansa. 
$\mathrm{K}$

iinnostavaa Harvan ja Kolin professuurien täyttämisessä oli, että heidän molempien kohdalla rima heilui, jopa pompahteli. Mutta yliopistomaailmassa ei tällaisia hipomisia illata. Ylityksen jälkeen kenellekään ei jäänyt epäselväksi näiden kahden miehen suuri vaikutusvalta myöhempinä vuosina. Tosin rehtorin työ 40-luvulla ja 60luvulla oli varsin erilaista. Harvan kolmen vuoden toimikaudella putosi opiskelijamäärä 708:sta kuudella henkilöllä. Sen sijaan Kolin rehtorina ollessa se nousi kuuden vuoden aikana 1500:sta lähes viisinkertaiseksi.

\section{Oligarkia-puhe}



ndividualisti Harvalle ja organisaattori Kolille oli yhteistä se, että he pyrkivät saamaan aikaan sekä suuria että pieniä muutoksia suomalaisessa yhteiskunnassa. Millä keinoin he tähän päämäärään etenivät? Molemmat ymppäsivät yliopistoluentoihinsa runsaasti omaa ideologiaansa. Siihen aikaan muuten myös rehtorit jatkoivat peruskurssien ja muiden luentojen pitämistä lisääntyvistä hallinnollisista rasitteista huolimatta. Urpo Harvan iskevimmät välineet olivat ohuehkojen kirjojen julkaiseminen, mutta erityisesti jatkuva polemiikki aikakaus- ja sanomalehdissä. Aamulehdessä hän ehti 33 vuoden aikana julkaista yhteensä yli 500 kirjoitusta, joista eläkeläisen pakinoita Tavin tornista (hän asui Järvensivun Tavintiellä) oli noin 200. Urpo Harva oli armoitettu keskustelija ja tyhmempiensä ärsyttäjä. Luulen, että hän tahallaan etukäteen mietti, mitkä kysymykset eniten ihmisiä irritoivat. Hänen pienen huulipartansa takaa välähtävä virnistys oli selvä merkki siitä, että luoti oli löytänyt paikkansa. Hän oli mielestäni ensimmäinen "päivystävä Tampereen dosentti”, selvästi ennen Pertti Hemánusta.

Paavo Koli ei ehtinyt tieteen poluilla samanlaiseen tahtiin kuin Urpo Harva. Siinä nuorukaisen iässä, kun Harva valmisteli väitöskirjaansa ja pohdiskeli filosofi Hartmanin käsitystä siitä, miten paha ja itsekäs ihminen pohjimmiltaan on, joutui koulupojasta hetkessä sotilaaksi muuttunut Koli konepistoolinsa ja pioneerimiinojensa kanssa hoitamaan näitä pahuuden ilmenemismuotoja Karjalan metsissä. Urpo Harva oli saanut lääkärintodistuksen perusteella vapautuksen sotapalvelusta.

Toisaalta Kolin rajun respiittipaineen alla kirjoittama teos Organisaatio ja johtajuus oli kovin suosittu oppikirja sekä yliopistoissa että myös yrityselämän piirissä. Paavo Kolin suurin merkitys on sittenkin hänen huolella valmistelluissa puheissaan ja esitelmissään, joita hän ehti lyhyeksi jääneellä urallaan pitää sadoittain. Enpä tunne montaakaan professoria, jonka tavallisista arkipäivän luennoista olisi jäänyt niin paljon oppilaiden mieliin vuosikymmenien ajaksi kuin Kolin opetuksessa. Hän osasi "lukea tiedettä" - kuten ammattitermi kuuluu - siis välittää sitä eteenpäin laajempiin piireihin, tosin omilla painotuksilla väritettyinä. Haastatteluaineistoni pursuu sellaisia detaljeja ja episodeja. Hänen lukuvuoden avajaispuheitaan aina odotettiin suurella kiinnostuksella. Esimerkiksi nykyisen arkkipiispan isä, tuomiorovasti Oskari Paarma saapui aina kuuntelemaan rehtori Kolin lukuvuoden avajaispuheita, koska ne hänen mielestään kuulostivat "kirkonkellojen kilinältä", vaikkei hän aina sosiologisista pitkistä sanoista mitään ymmärtänytkään. Koli tiesi itsekin puheittensa tenhon. Hän oli oppinut myös elämään symbioosissa median kanssa, mikä taito vieläkin näyttää yliopistopiireissä olevan harvinaista. Esimerkiksi vuoden 1966 oligarkiaa käsitelleen avajaispuheen etukäteisvalmistelut olivat huolellisia. Puhe luetutettiin luottokollegoilla. Minut hän pisti soittelemaan sanomalehtiin ja kertomaan, että nyt on tulossa todellinen "pommipuhe". Olavi Borg ehdotti eräitä lievennyksiä puheeseen, mutta Koli vastasi hänelle: "Minä olen pioneeriupseeri, minä tiedän miten panos räjäytetään!’. Eivätkä Kiestingin motin ja Karhumäen opetukset olleet menneet hukkaan, pommi räjähti.

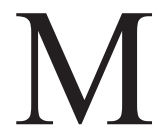

iksi tuo puhe oli sitten niin merkitsevä, että sitä kannattaa muistella vielä 35 vuoden kuluttuakin? Elettiin ensinnäkin aikaa, jolloin presidentti Kekkonen oli saanut jo vyörytettyä omille ajatuksilleen ja kannattajilleen vankat jalansijat. Toisaalta yliopistolaitoksessa elettiin vielä samanlaista professorien rikkumattoman vallan aikaa kuin 1930-luvullakin. Koli heitti pomminsa molempien vallankäyttäjien jalkoihin. Hänen 
puheensa ydin tiivistetysti se oli, että poliittiset vallankäyttäjät ja heidän valtaamansa opetusministeriö olivat nielaisemassa yksittäisten korkeakoulujen autonomian. Hänen purevan kritiikkinsä kohde oli opetusministeriöstä ja korkeakouluneuvostosta annetut uudet asetukset, jotka olivat hänen mielestään viemässä yhteiskuntaamme suurin hyppäyksin demokratiasta kohti oligarkiaa. Koli pamautteli suoraan juhlasalimme katederilta väitteet, joiden mukaan yksi poliittinen ryhmittymä oli saamassa korkeakoulutuksen alueella täydellisen vallan. Hän kertoi nimiä mainitsematta, miten opetusministeriön korkeakoululinjan kaikki kolme korkeata virkamiestä tunnustavat samaa poliittista väriä. Hän tarkoitti ensiksi kansliapäällikköa, myöhempää opetusministeriä Heikki Hosiaa, YKK:n kasvattia, joka oli myös ylioppilaskuntamme kunniajäsen (kuten muuten Urpo Harva, Paavo Koli ja jopa minäkin), toiseksi tiede- ja korkeakouluosaston päällikköä Helsingin yliopiston filosofian professori Oiva Ketosta, joka vei Eino Kailalta periytyneen nimekkään viran juuri Urpo Harvan nenän alta sekä kolmanneksi korkeakoulutoimiston päällikköä Jaakko Nummista, ainoaa elossa olevaa tässä vallankäyttäjien sarjassa, arvoltaan nykyisin ministeri. Siis nykykielellä kyseessä oli kirkas keskustapuolueen värisuora ${ }^{2}$. Sotasankarinkaan rohkeus ei yltänyt siihen, että Koli olisi kääntänyt pakasta vielä neljännenkin kortin, saman suoran kuninkaan, presidentti Urho Kekkosen (joka myös oli Tampereen yliopiston ylioppilaskunnan kunniajäsen). Tai sitten Koli noudatti vielä pirullisempaa, mutta varsin tuloksellista juonta, jota hän erään sotaveteraanin minulle kertomana noudatti Kiestingin soilla Vienan Karjalassa vuonna 1942.

20-vuotias vänrikki Koli oli silloin joukkueensa kanssa ylittämässä aavaa, puutonta suota. Yht'äkkiä he havaitsivat vihollisen seitsemän hävittäjäkoneen lähestyvän. Miehillä ei ollut minkäänlaista mahdollisuutta suojautua ja heidän pelokkaat katseensa kohdistuivat johtajaansa. Silloin Paavo Koli käytti sitä asetta, mitä hän onnistuneesti viljeli myöhemminkin yliopistomaailmassa taistellessaan. Hän käski terävästi kaikkia miehiään vilkuttamaan iloisesti koneille. Hävittäjät tervehtivät siiven liikkeillä omiksi luulemiaan ja häipyivät. Johtajalla oli tuolloin aikaa päätöksentekoonsa viisi sekuntia, mutta Paavo Koli käytti tilanteeseen nähden tämän ajan oikein ja pelasti kaikki miehensä varmalta kuolemalta. "Mutta kyllä minä pelkäsin", kertoo Kanadassa 50 vuotta asunut 82 -vuotias entinen metsuri vieläkin.

Ehkäpä rehtori Koli käytti samanlaista taktiikkaa myös oligarkia-puheessaan. Siihen aikaan oli maahamme jo alkanut muodostua lievähköä kahden kielitason kulttuuria, ei kuitenkaan niin selvää ja dramaattista kuin esimerkiksi Puolassa ja Unkarissa. Puheet pidettiin omalla retoriikalla, mutta joillakin avainsanoilla viestittiin todellinen tarkoitus. Niinpä tiedotusvälineet iskivät heti kiinni olettamaansa piilokieleen. Kolin hyökkäyksen kohteena oli erityisesti professori Ketonen, joka osastopäällikön lisäksi oli määrätty juuri perustetun korkeakouluneuvoston ja jopa sen kaikkien jaostojen puheenjohtajaksi. Ketonen tiedettiin Kekkosen tähän asemaan nostamaksi mieheksi, jolloin kuvio näytti selvältä. Paavo Kolin ampuma nuoli tietenkin kimmahti Ketosen kylkiluusta itse maaliin, Kekkosen kiukkusuoneen. Muuta ei tarvittu. Maanlaajuinen debatti tiedostusvälineissä alkoi. Presidenttikin äityi pariin Kolille lähettämään myllykirjeeseen, jotka ovat luettavissa yliopistomme kirjastossa. Tällainen poliitikkoja säikäyttänyt avajaispuhe varmaankin väikkyy monen tämänpäivän yliopistorehtorin päiväunissa. Valitettavasti vain yhteiskunta on muuttunut Kolin ajoista responsiivisemmaksi, vastaanottavaisemmaksi. Nuolet eivät enää jaksa kimpoilla mihinkään, uppoavat vain ylitsepursuavaan informaatiotaikinaan.

Tuskinpa nykyisessä ilmapiirissä yliopiston hallintojohtajalta onnistuisi sama kuin hänen edeltäjältään Yrjö Silolta. 60-luvulla eräs korkeakoulumme lehtori kirjoitti Kansan Lehteen omalla nimellään kirjoituksen, jossa hän arvosteli voimakkaasti neljä vuotta vanhan yliopistomme päärakennuksen teknisiä vikoja, mm. ilmastointia ja liian suuria ikkunoita. Myös toisen rakennusvaiheen suunnitelmia kritisoitiin ja vedottiin kaupungin johtajiin. Rehtori Paavo Kolia kirjoituksessa kehuttiin, mutta arkkitehti Toivo Korhosta ja kokoomuslaista Yrjö Siloa arvosteltiin. Sen ajan poliittisia verkostoja ja akseleita kuvannee, että sosialidemokraattisen lehden painokoneet pysäyttiin 13.10 .1964 yöllä klo 22.30 ja kirjoitus poistettiin koneista. Tällaista oli hallintokulttuuri 
siihen aikaan Tampereella! Löysin tämän sensuroidun kirjoituksen pari päivää sitten kirjastomme hyllyltä pieneen kansioon säilytettynä ja ilmeisesti jälkipolvien nähtäväksi tarkoitettuna. Todettakoon, että päärakennuksen ilmastointi korjattiin tänä vuonna!

Rehtori Kolin puhe sisälsi taitavasti harkittuja tieteellisiä käsitteitä, joilla kuitenkin oli tunneperäinen, herravihainen, kansanomainen lataus. Tahallinen vai tahaton? Liekö tämäkin opittu syksyllä 1941 Kiestingin kolmeviikkoisessa motissa, jonka syntymisen ja viivyttämisen tuhansien suomalaisten sotilaiden uhraamisen hinnalla vänrikki Koli upseeritovereineen koki olevan kenraalien kapean ja vaihtoehdottoman johtamistaidon syytä. Myös kaikissa teollisuussosiologian kirjoissaan professori Koli ilmaisi kiinnostuksensa tavallisten työntekijöiden asemaan ja työpaikkojen ilmapiiriin. Eräs tällainen yhteiskuntatieteellinen termi, jota Koli käytti oligarkiapuheessaan, oli kooptio eli naamiointivaali. Hän väitti, että opetusministeriön värisuora "revisiomentaliteetillaan", "autoritaarisena" ja "demonisena" syöksee yliopistot "byrokratian syövereihin". Nämä sivistysanat pistivät kansankin veren kiertämään. Koli väitti, että näennäisen demokraattisilla kooptiovaaleilla valittaisiin Suomen korkeakouluja edustamaan korkeakouluneuvosto, jonka valintaan yksittäisillä korkeakouluilla ei olisi paljonkaan todellista sananvaltaa.

Koli sai tällä puheellaan myös tavallisen kansan suuren suosion. Sitä osoittavat lukuisat senaikaiset yleisönosastokirjoitukset. Esimerkiksi eräs Uuden Suomen nimimerkki kirjoitti, ettei Kekkosen läheisellä neuvonantajalla ja korkeakouluneuvoston varapuheenjohtajalla Kustaa Vilkunalla olisi oikeutta edes sitoa Paavo Kolin kengännauhoja. Hänestä tuli median suosima julkkis. Tampereen yliopiston nykyiset opiskelijat ja jopa eräät nuoremmat opettajatkin kysyvät, miksi eräs yliopiston luentosaleista on nimitettu Paavo Koli saliksi. He epäilevät Kolin olleen joku maaherra tai vastaava. Heille vastaan kireästi, että hän oli yliopiston rehtori, joka sijoittui vuonna 1967 erään aikakauslehden mielipidetiedustelussa vuoden 1974 tasavallan presidentin vaalien kandidaattien kilpailussa neljännelle sijalle, lyöden laudalta mm. sellaiset monille tutummat nimet kuten Ahti Karjalainen ja Mauno Koivisto.

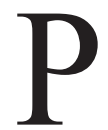

aavo Kolin kirjoitukset 1960-luvulla osoittivat hänen olleen poikkeuksellisen lahjakas tulevaisuuden ennustaja. Esimerkiksi hänen ajatuksensa kirjastojen muuttumisesta tietokonepohjaisiksi, avoimesta yliopistosta, täydennyskoulutuksesta, sähköisestä etäopiskelusta, kansainvälisestä opiskelijavaihdosta, pätkätöiden lisääntymisestä jne. ovat kaikki toteutuneet noin 30 vuotta myöhemmin. Istuessani itse lopetettavan korkeakouluneuvoston jäsenenä sen viimeisessä kokouksessa vuonna 1995 minun ajatukseni lensivät Paavo Kolin yliopiston avajaispuheeseen tasan 30 vuotta aikaisemmin. Myös tämän kooptioelimen lopun hän sittenkin oli ennustanut. Kolin alkuun potkaiseman kritiikin vuoksi korkeakouluneuvostoa nimittäin uusittiin jo vuosi perustamisensa jälkeen. Kolin voimakkaan arvostelun kohteena oli ollut juuri se, että korkeakouluilla ei ole paljoakaan sananvaltaa valittaessa jäseniä korkeakouluneuvostoon. Tästä kritiikistä seurasi, että korkeakoulujen rehtorit kokoontuivat yhteen tekemään ehdotuksia heille sopivista ja pätevistä ehdokkaista. Näistä epävirallisista kokouksista sai alkunsa nykyinen Suomen yliopistojen rehtorien neuvosto, joka ei sekään ole kovin voimakasta painostajan roolia kyennyt valtaamaan itselleen taistellessaan vallasta opetusministeriön virkamiesten kanssa. Korkeakouluneuvoston jäsenten valinta sai aina aikaan kuhinaa kentällä ja puoluetoimistoissa. Minua pyydettiin vuonna 1993 tämän neuvoston jäseneksi täyttääkseni paikan, johon etsittiin alle 50-vuotista naista, joka on kasvatustieteen tohtori. Sain paikan, vaikken täyttänyt yhtään näistä kriteereistä. Se oli kai sitä kooptiovaalin taktiikkaa parhaimmillaan!

Toinen kiistatta todennettava, Kolin vääräksi moittima suunta kääntyi hänen ajatustensa mukaiseksi: Tampereen yliopiston opiskelijamäärän opetusministeriö halusi supistaa 15 vuodessa 5000 opiskelijasta 4500:aan, kun samaan aikaan muiden yliopistojen opiskelijamääriä kasvatettiin. Todellisuudessa Paavo Kolin vyörytysten (tämä termi sopii hyvin häneen) ansiosta opiskelijamäärä kasvoikin kaksinkertaiseksi eli lähes 9000:ksi vuonna 1981. Koli ponnisteli rajusti myös matemaattis-filosofisen tiedekunnan perustamiseksi vuonna 1966. Miinat, pommit ja 
railakkaat adjektiivit eivät auttaneet silloin. Mutta sittenkin, siemen oli kylvetty. Vasta tänä syksynä, 35 vuotta myöhemmin, tämä tiedekunta sittenkin syntyi, tosin toisella nimellä.

\section{Henkilö ja ääni}



asemmiston, maalaisliiton ja erityisesti Urho Kekkosen leppymätön, jopa patologinen vastustaja ja YKK:n professorien Kauko Sipposen, Yrjö Littusen, Antti Eskolan ja Pertti Hemánuksen ilkkuja Kauko Kare on tunnetussa kirjassaan "Tähän on tultu" pitkään ja innostuneesti lainannut Paavo Kolin harvainvaltapuhetta. Pettyneenä hän kuitenkin toteaa Kolin "säikähtäneen". Katkerana hän kirjoitti, miten Koli "hätäännyksen vallassa" meni Aamulehdessä torjumaan viittaukset presidenttiin ja jopa alentui kehumaan silloista opetusministeri Johannes Virolaista ansioituneeksi ja asialliseksi korkeakoulupoliitikoksi. Sen sijaan Urpo Harvasta Kauko Kare sai itselleen yllättävän adjutantin, jopa työteliään propagandistin. Harva julkaisi vuonna 1969 kirjasen nimeltään Alas professorit; Kulttuuripoliittinen ajankuva nykySuomesta. Se kuului Kauko Kareen kustantamaan TPJ-kirjojen sarjaan. Nämä kolme kirjainta olivat lyhennys sanoista "terveen järjen puolustus". Yleensä tasaisen rauhallinen, ilkikurinen sivaltaja Urpo Harva kadotti tyyneytensä, kun Jaakko Nummisen johtama komitea esitti Suomen korkeakouluihin uutta hallintomallia, joka olisi perustunut henkilö ja ääni -periaatteel$\mathrm{le}^{3}$. Harva pani kaikkensa peliin, kirjoitti $\mathrm{mm}$. pitkiä tekstejä hidastuspuheita varten kyseisen lakiluonnoksen ollessa eduskunnan käsittelyssä. Harvan julkaisemien teosten rivistössä tämä TPJ-kirja töksähtää esiin tyylirikkona. Toisaalta hänen itsensä kirjoittamat lakiluonnosta vastustavat sivut ovat näin jälkeenpäin luettuina varsin loogisia ja asiallisia. Mutta tiedemiehen ja filosofin arvovallan luovuttaminen populistisen Alea-Kirja Oy:n käyttöön ihmetyttää Urpo Harvaa tunteneita vieläkin. Hänen "Alas professorit" -kirjansa takasivua muun muassa koristaa piirros, jossa sakilaisen näköinen polvihousuinen Johannes Virolainen ylioppilaslakki päässään potkaisee yliopiston rehtorin katederilta alas niin että käädyt ja viitat heilahtavat.
Otan pienen esimerkin Harvan kirjassa esiintyneestä kirjoitustyylistä, jota Kareen toimittama lehti "Nootti" käytti erityisesti kyseistä hallintomallia ajaneesta ministeri Virolaisesta: "Myös meidän Johanneksemme, Hra Opetusministeri, on suosittu ja käytetty Kultasuu (tässä viitataan neljännellä vuosisadalla eläneeseen kreikkalaiseen Johannes Krysostomukseen eli ‘Kultasuuhun'). Hänen sanansa solisevat vuolaana virtana niin lammasnäyttelyiden lavoilta kuin korkeakoulujen kateedereilta. Ei ole hänen vikansa, että äänen pondus on hieman päkättävä. Millaisen seuranäyttämötaiteilijan Runo-Suomi menettikään, kun mies uhrautui ministeriksi." Ja edelleen: "Kun agraarinen ahdasotsaisuus yhdistyy massojen kosiskeluun, vallan korskeus liehakointitarpeeseen, ollaan Virolaisen-Nummisen linjalla." Tunnustan, että itse joskus jopa kaipaan tällaista kieltä nykyisessä, pliisun konsensuksen korkeakoulupolitiikassa.

Kun edellä on todettu Paavo Kolin monien aloitteiden ja ennusteiden toteutuneen myöhemmin, on sanottava, että myös tämä Urpo Harvan ajama tavoite toteutui. Suomen korkeakouluihin ei tullut henkilö ja ääni -periaatteen mukaista hallintoa, ei edes sairaaloihin tai puolustusvoimiin, vaikka Virolainen näin lupasi. Sen sijaan Virolainen sai aluksi vaaleissa kansalta rangaistuksen seikkailuistaan, mutta hänkin nousi uudelleen monenlaisten näyttämöiden lavoille, jopa laulusolistiksi. Siinä osui Kauko Kareen pilkka harhaan, Suomi ei sittenkään menettänyt näyttämötaiteilijaa! Mutta korkeakouluihin hän ei enää viiden metrin kepilläkään koskenut, lainatakseni tätä poliittista inhoa osoittavaa uusinta mittayksikköä.

Harvan ja Kolin habituksen erot ja yhtäläisyydet

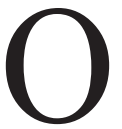
len pintaa raapaisten kuvaillut kahden Tampereen yliopiston rehtorin korkeakoulupoliittiseen valtaan liittyviä toimintoja. Monista asioista he olivat yhtä mieltä, mutta melkein yhtä monessa asiassa he olivat barrikadin eri puolilla. Heidän habituksestaan oli helppo löytää eroja. Urpo Harva asteli yliopiston käytäviä arvokkaan rauhallisesti tirolilaishattu toisessa ja kävelykeppi toisessa kädessään. Paavo 
Koli marssi ryhdykkäänä pitkin harppauksin kovalla vauhdilla kättään tutuille heilauttaen. Molemmille herroille oli yhteistä hyvin istuvat puvut. Merkittävä ero oli siinä, että Koli rehtorinakin olleessaan pystyi vaihtamaan muutaman sanan kenen tahansa alimman palkkaluokan kanslia-apulaisen kanssa. Se ei Harvalle sopinut. Jo sodassa saivat tavalliset pienviljelijä-rivimiehet sinutella luutnantti Kolia virallisen palveluksen ulkopuolella. Kun kaksi yliopistomme professoria Väinö Heikkinen ja Seppo Mustonen sekä rehtori Koli katsastivat Rautatienkadun varrella yliopiston uusille tiedekunnille sopivia tiloja, Koli ihmetteli, miksi kaksi saman yliopiston professoria teittittelevät toisiaan. Hän ehdotti heidän olevan toisilleen vain Väinö ja Seppo, mutta Heikkinen piti entistä tyyliä parempana ja kieltäytyi. Myös Urpo Harva asettautui erilaisten seminaarien ja illanviettojen sinuttelukauppojen ulkopuolelle toivoen ääneen, et-teivät nämä yleiset tuttavuussopimukset kuitenkaan koskisi häntä.

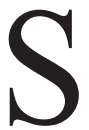

uhtautumisessa opiskelijoiden oikeuteen osallistua yliopiston hallintoon edes parin edustajan voimalla oli Harvan ja Kolin välillä selvä ero. Koli piti tällaista opintodemokratiaa yliopiston elinehtona. Harvan mielestä tiedekuntien ja laitosten kokouksessa ei yleensä käsitellä sellaisia asioita, joissa opiskelijoiden panosta tarvittaisiin. Itse kävin juuri näistä asioista Harvan kanssa jatkuvaa kinastelua lehtien palstoilla. Eräässä vastineessaan minulle Urpo Harva taas kerran yllätti: hänen mielestään opiskelijat voisivat hallinnollisen osallistumisen sijasta arvostella toistensa pro gradu työt sekä arvioida uusien opettajien opetusnäytteet. Samalla hän vaati myös opintosihteereitä lisää ja edellytti heiltä tohtorin arvoa. Tai sitten hän taas kerran harvamaisesti vain hämäsi ja ärsytti. Kuten silloin kun hän 30-luvulla oli Sääksmäen Päivölän kansanopiston rehtorina pistänyt kaulaansa punaisen kravatin, jota naapurissa sijainneen maatalousoppilaitoksen opiskelijat voimakkaasti paheksuivat. Siitä tehtiin jopa kantelu kouluhallitukselle. Pukipa Harva kerran päälleen natsisotilaan uniformunkin vieraillessaan Saksassa 30-luvulla. "Oli mahtava tunne", sanoi Harva ja tarkoitti sillä taas kerran jotakin muuta. Samaa luokkaa oli hänen rienaamisensa, kun hän yllät- täen ainoana vastapuolen edustajana osallistui Tampereen yliopiston opiskelijoiden lakkokokoukseen juuri tässä luentosalissa. Kun kaikkien puheiden teemana oli, että valtaa pitää hajoittaa, Harva nousi puhumaan ja sanoi, että "vain harvalle kannattaa antaa valtaa". Sen lisäksi hän kertoi, että hän lukee vain puolueettomia lehtiä, kuten Aamulehteä ja Uutta Suomea. Radikaalien lakkolaisten auktoriteetti-ihailu taisi paljastua, kun Harva sai puheelleen runsaat aplodit. Ja tuskinpa monikaan on uskaltanut keskeyttää yliopiston lukuvuoden avajaisten opiskelijan puheenvuoron huutamalla etupenkistä: "Se on kyllä valetta!"

Urpo Harva ei pitänyt lainkaan rehtori Kolin vauhdikkaan dynaamisesta halusta laajentaa Yhteiskunnallista korkeakoulua. Hän jopa vastusti sen muuttamista Tampereen yliopistoksi. Koli taas Mannerheim-ristin ritarina oli jo nuorena nähnyt, ettei mitään saa, jollei sitä itse ota. Hän ei pelännyt valtaa pitäviä ja inhosi yliopistojen seisovan veden strategioita. Hän siirsi sodan ankarissa oloissa oppimaansa kansan kieltä akateemiseen jähmeyteen. Niinpä hän uskalsi julkisesti todeta, - tosin kieltään anteeksi pyydellen - että yliopistoissa - myös Tampereella - on paljon "liimaperseitä", siis opettajia ja tutkijoita, jotka eivät halua professorin tuoliltaan nousta minkään uudistuksen taakse. Hän myös nimitti yliopiston rehtorin tehtäviä "kusitolpaksi", johon kaikenlaiset yliopiston tyypit käyvät jalkaansa nostamassa. Kolin näki yliopiston johtamisen vaikeaksi tehtäväksi todeten, ettei yliopisto olekaan mikään Alma Mater, "hellä äiti", vaan pikemminkin ankara Pater, joka ei halua tunnustaa omakseen heikkoja jälkeläisiään. Tämä vertaus sopii mielestäni hyvin tähän päivään. Ankara Pater eri pidä opinnoissaan viivästyneistä eikä opintonsa keskeyttäneistä. Sekä Kolin että Harvan kohdalla pätee organisaatioteoreettinen yleistys: "Tapa, miten johtaja suhtautuu henkilöstöön, perustuu hänen ihmiskäsitykseensä.”

Kummankin herran habitukseen kuului, että toinen sukupuoli piti heitä varsin kiinnostavina. Paavo Kolia sanoivat aina sodanajan lotista lähtien "komeaksi" ja "ryhdikkääksi herrasmieheksi". Kun fuksina ihmettelin opiskelijatovereitteni, siis 18-19 -vuotiaitten naisten suurta kiinnostusta melkein 50-vuotiaaseen Urpo Har- 
vaan, sain vastaukseksi: "Kun hän melkein riisuu meidät katseellaan." Tänä päivänä tällainen lause tuottaisi vakavia juridisia seuraamuksia.

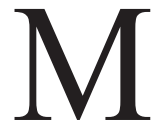

itä tekisivät Paavo Koli ja Urpo Harva nyt, joulukuussa 2001? Koli olisi varmaankin juuri saanut hankituksi Tampereen yliopistolle muutaman kymmenen miljoonaa markkaa amerikkalaisilta säätiöiltä eräisiin innovatiivisiiin tutkimushankkeisiin. Harva todistelisi Ajankohtaisen kakkosen ohjelmassa islamin uskon olevan todellisuudessa väkivallatonta ja naisia suojelevaa sekä käsittelisi Aamulehden pakinassaan hullun lehmän taudin sekä Tammerkosken yli suunnitellun sillan vaikutuksia ihmisten elämään bioetiikan ja ekologisen teologian kannalta katsottuna.

Urpo Harva teki verkkaisan ja pitkän päivätyön ja jaksoi vielä parikymmen- tä vuotta eläkkeeltäänkin heitellä julkisuuteen mielipiteitä, jotka yleensä edustivat vähemmistön käsitystä tästä maailmanjärjestyksestä. Loppuun saakka hän ilmoitti karsastavansa kaikenlaista valtaa, vaikka jokaisella pakinallaan ja puheellaan hän sitä eittämättä harjoitti. Paavo Kolille annettiin ratkaisuvaltaa toisten ihmisten elämästä ja kuolemasta jo 18-vuotiaana. Hän käytti sitä taiten. Esimerkiksi 10-tuntisessa taistelussa, josta hänet palkittiin Mannerheim-ristillä, kaatui noin 200 vihollista, viimeiset kuuden metrin päähän Kolista, eikä hänen joukkueestaan kukaan saanut naarmuakaan. Paavo Koli teki elämässään paljon pää- töksiä, myös sen, minkä pituisen elämän hän itselleen halusi.

Tässä on kuvaus kahdesta kovin erilaisesta professorista ja yliopiston rehtorista. Tampereen yliopisto salli heidän paljastaa parhaat kykynsä erilaisissa rooleissa. Kun raskas sota oli päättynyt, elettiin vuotta 1945. Minä aloitin silloin opintoni kansakoulussa, Paavo Koli yliopistossa ja Urpo Harva aloitti pienen korkeakoulumme rehtorina. Kolmen ihmisen elämän aikajänne oli siis näin pitkä, mutta silti me ehdimme vuosikausia tehdä töitä samojen käytävien varrella, istua yhdessä lounaalla ja joskus jopa konjakillakin. Yksi meille oli yhteistä: Tampereen yliopisto. Tämä yliopisto omaperäisine persoonallisuuksineen loi sen ympäristön ja ilmapiirin, joka tällaistenkin erilaisten elämänkokemusten symbiosin teki mahdolliseksi.

\section{Viitteet}

1 Professori Matti Parjanen piti jäähyväisluentonsa Tampereen yliopistossa 12.12.2001.

2. Opetusministerinä oli tuolloin R.H. Oittinen (SDP) ja hallitus oli Paasion hallitus (1966-68). Oittinen oli opetusministerinä peräti viidessä hallituksessa vuosina 1948-68 ja siten yksi pitkäaikaisimpia sotienjälkeisiä ministereitämme. (Viljo Ripatti. R.H. Oittinen. Tammi 1992)

3. Harvan tavoin myöskään Paavo Koli ei kannattanut mies ja ääni -periaatetta. Varsinainen taisteluntemmellys asiasta ajoittui kuitenkin Kolin kuoleman jälkeen. 